REPORTS OF MORPHOLOGY
Official Journal of the Scientific Society of Anatomists,
Histologists, Embryologists and Topographic Anatomists
of Ukraine
journal homepage: https://morphology-journal.com

\title{
Modeling of individual teleradiographic indicators according to the Steiner method for Ukrainian young men with wide and young women with a very wide and wide face types
}

Drachevska I.Yu.

National Pirogov Memorial Medical University, Vinnytsya, Ukraine

ARTICLE INFO

Received: 08 July 2021

Accepted: 07 August 2021

UDC: $616.314 .2-007.271-$

053.7:617.52:616-073.75

\section{CORRESPONDING AUTHOR}

e-mail: idra4evskaya@gmail.com Drachevska I.Yu.
Cephalometric methods of analysis of lateral teleradiograms are one of the key elements of orthodontic planning of treatment of a patient with pathology of the dental-jaw system. Determining normative teleradiographic indicators for the local population is a key step for the successful application of one or another method of analysis, in particular, for Ukraine. The aim of the study was to construct and analyze regression models of teleradiographic parameters used in the Steiner method for Ukrainian young men and young women with orthognathic occlusion with different face types. 49 young men and 76 young women with orthognathic occlusion in the software OnyxCeph ${ }^{3} \mathrm{TM}$, version 3DPro, the company Image Instruments GmbH, Germany (license № URSQ-1799) conducted a cephalometric study using the Steiner method. The division into facial types was performed using the Garson index. Cephalometric parameters were divided into three groups: the first - indicators used in cephalometric analyzes of Schwarz, Ricketts, Steiner, Roth-Jarabak, Burstone and Bjork and are included in the parameters that usually do not change during surgical and orthodontic treatment; the second - dental-maxillary characteristics according to the Steiner method which surgical methods can be used to change the length, width, angles and position of the jaws; third - indicators according to the Steiner method that characterize the position of each tooth relative to each other, cranial structures and the profile of the soft tissues of the face. Modeling of individual teleradiographic indicators was performed in the licensed package "Statistica 6.0" using step-by-step regression analysis. When analyzing reliable models of teleradiographic indicators according to the Steiner method, which were included in the second group depending on the indicators of the first group with a coefficient of determination higher than 0.6, it was found that out of 7 possible, 5 models were built for young men with a wide face type, which most often include the value of the distances Ar-Go and $N$-S and the angles $H$ and $N$-S-Ar; young women with a very wide type of face - 3 models ( $R^{2}=$ from 0.604 to 0.812 ) which most often include the value of the angles $\mathrm{N}-\mathrm{S}$-Ar and $\mathrm{H}$; in young women with a wide type of face - 4 models $\left(R^{2}=\right.$ from 0.694 to 0.771$)$ which most often include the value of the angles POr-NBa and $\mathrm{H}$, the distance P-PTV and the ratio S-ar:arGo. When analyzing reliable models of teleradiographic indicators according to the Steiner method, which were included in the third group depending on the indicators of the first and second groups with a coefficient of determination higher than 0.6, it was found that out of 8 possible in young people with a wide face type, 7 models were built $\left(R^{2}=\right.$ from 0.662 to 0.946). which most often include the magnitude of the angles $A N B$ and $S N-G o G n$ and the distance $P$-PTV; in young women with a very wide face type -4 models $\left(R^{2}=\right.$ from 0.635 to 0.844) which most often include the value of the angles ANB, SNA, POr-NBa and the distance Pog-NB; in young women with a wide type of face - 6 models $\left(R^{2}=\right.$ from 0.617 to 0.923), which most often include the value of the distances Pog-NB and N-CC and the angle ANB. Construction of regression models of teleradiographic indicators used in the Steiner method in Ukrainian young men and young women with orthognathic occlusion is the foundation for creating a database of normative cephalometric indicators in Ukraine, which will provide dental care to the population at the current level.

Keywords: regression analysis, teleradiography, Steiner cephalometry, young men and young women with orthognathic occlusion, facial types. 


\section{Introduction}

Orthodontics is one of the branches of dentistry that requires the practitioner not only to understand the basic anatomical concepts of the entire face, dental apparatus and features of orthodontic pathology, but also a certain understanding of the aesthetic beauty of the face, the ability to predict the end result of treatment.

However, the implementation of this type of treatment, relying only on experience and "premonition" and a view of the beauty of an orthodontist is not acceptable in modern conditions. Therefore, the scientifically proven method currently used by physicians to plan the results of orthodontic care is cephalometric analysis [2].

Thus, the importance of using this method is evidenced by studies by A.R.Durńo and co-authors [7] where 43 patients underwent orthodontic treatment without the use of cephalometric method, with the participation of doctors of two conditional categories - experienced and inexperienced orthodontists. However, as a control during the first visit, a cephalometric analysis was performed to predict treatment outcomes. At the end of treatment, the results were compared - how well the orthodontists achieved the desired result, calculated by cephalometric analysis. As it turned out, inexperienced orthodontists had a success rate of $28 \%$, and experienced $-67 \%$.

Although there are studies that indicate that the cephalometric method of analysis is not required for use in orthodontic treatment. As shown by statistical analysis the use of this method does not significantly affect $(p=0.80)$ the choice of orthodontic treatment when planning treatment of the patient [10].

The key to solving this problem would be the related use of both the experience of an orthodontist and cephalometric analysis using neural networks to calculate cephalometric parameters and three-dimensional research methods such as CT and MRI [12].

Indeed, modern medicine requires scientists to use the latest methods to improve orthodontic treatment or improve existing ones. All this occurs against the background of increasing the number of antenatal and postnatal risk factors for this type of pathology, in particular, changes in the functioning of the masticatory apparatus, increasing the number of comorbid somatic diseases, bad habits, deteriorating socio-economic conditions, etc. [13].

One of the priority measures to be taken is the adaptation of teleradiography indicators for the local population. The fact that taking the ethnic component into account in studies of this kind is fundamentally important has already been proven [4]. Thus, in particular, it is insufficient to study the average indicators of a group of peoples, because the indicators can be radically different, even within one such group [8]. Moreover, odontological indicators can differ strikingly even within one homogeneously populated country depending on one or another region [9].

All these facts indicate the need for continuous improvement of existing data, and their refinement, using as many variables as possible.

The aim of the study was to construct and analyze regression models of teleradiographic parameters used in the Steiner method for Ukrainian young men and young women with orthognathic occlusion with different face types.

\section{Materials and methods}

49 young men and 76 young women with orthognathic occlusion in OnyxCeph ${ }^{3 \mathrm{TM}}$ software, 3DPro version, Image Instruments $\mathrm{GmbH}$, Germany (license № URSQ-1799) underwent a cephalometric study using the Steiner method. Cephalometric points were determined according to the recommendations of Phulari B. S. [17] and Doroshenko S. I. and Kulginsky E. A. [5].

To divide into facial types, the morphological index of Garson was determined [18]. The following distribution is established: young men - 5 with a very wide face, 22 with a wide face, 11 with a medium face, 8 with a narrow face; young women - 25 with a very wide face, 25 with a wide face, 10 with a medium face, 12 with a narrow face.

Cephalometric parameters were divided into three groups [3]: the first - cephalometric measurements used in the analyzes of Schwarz, Ricketts, Steiner, Roth-Jarabak, Burstone and Bjork and are included in the basic parameters that usually do not change during surgical and orthodontic treatment; second - metric dental-jaw characteristics by the method of Steiner which surgical methods can change the length, width, angles and positions of the upper and lower jaws; third - indicators by the Steiner method that characterize the position of the teeth relative to each other, cranial structures and the profile of the soft tissues of the face.

Cephalometric parameters included in the first group: $\mathrm{N}-\mathrm{Se}$ - length of the anterior part of the skull base according to Schwarz $(\mathrm{mm})$; N-S - length of the front part of the skull base according to Jarabak (mm); N-CC - anterior length of the skull base by Ricketts (mm); S-E - length of the back of the skull base according to Steiner $(\mathrm{mm})$; S-Ar - length of the lateral cranial base according to Jarabak $(\mathrm{mm})$; P-PTV - distance of P-PTV by Ricketts (mm); Ar-Go - the length of the branch of the mandible by Burstone $(\mathrm{mm}) ; \mathbf{H}-\mathrm{H}$-angle by Schwarz $\left(^{\circ}\right)$; POr-NBa - cranial deflection angle according to Ricketts $\left({ }^{\circ}\right)$; N-S-Ba - angle N-S-Ba by Bjork $\left(^{\circ}\right)$; N-S-Ar saddle angle according to Bjork $\left(^{\circ}\right)$; S-Ar' - the distance of the joint by Bjork (mm); N-S:S-Ar' - the ratio of the distances S-Ar' and N-S in cephalometric analysis by Bjork (conventional units); S-ar:ar-Go - the ratio of the distances $\mathrm{S}-\mathrm{Ar}$ and Ar-Go in the cephalometric analysis by Jarabak (\%).

Cephalometric parameters according to the Steiner method [22], which belong to the second group: the SNA angle, characterizes the position of the upper jaw, namely the anterior contour, in the sagittal plane $\left(^{\circ}\right)$; SNB angle, characterizing the position of the lower jaw, namely the 
anterior contour of the chin, in the sagittal plane $\left({ }^{\circ}\right)$; angle ANB, characterizes the position of the lower jaw relative to the upper jaw, in the sagittal plane $\left(^{\circ}\right)$; SND angle, characterizing the position of the lower jaw, namely the center of the chin, in the sagittal plane $\left(^{\circ}\right)$; the angle $\mathbf{S N}$ GoGn, characterizes the inclination of the body of the mandible relative to the anterior cranial base $\mathbf{S}-\mathbf{N}\left({ }^{\circ}\right)$; the Pog-NB distance characterizing the position of the anterior contour of the bony chin relative to the line N-B $(\mathrm{mm})$; distance $\mathbf{S}-\mathbf{L}$, characterizes the position of the anterior contour of the mandible $(\mathrm{mm})$.

Cephalometric indicators according to the method of Steiner [22], included in the third group: angle II, characterizes the inclination of the upper and lower medial incisors relative to each other $\left(^{\circ}\right)$; the angle $\mathbf{S N}-\mathbf{O c P}$, characterizing the inclination of the closing plane relative to the anterior cranial base S-N $\left({ }^{\circ}\right)$; angle Max1-NA, characterizes the position of the upper medial incisor to the line $\mathrm{N}-\mathrm{A}\left({ }^{\circ}\right)$; angle Max1-SN, characterizes the position of the medial incisor to the anterior cranial base S-N ( $\left.{ }^{\circ}\right)$; angle Mand1-NB, characterizes the position of the lower medial incisor to the line N-B $\left(^{\circ}\right)$; distance 1u-NA, characterizes the position of the crown of the upper medial incisor in the boom plane relative to the line $\mathrm{N}-\mathrm{A}(\mathrm{mm})$; distance 1I-NB, characterizes the position of the crown of the lower medial incisor in the sagittal plane relative to the line N-B (mm); Holdaway Ratio, characterizes the position of the crown of the lower medial incisor in the sagittal plane relative to the bony chin Pog $(\mathrm{mm})$.

Modeling of individual teleradiographic parameters in young men with wide and in young women with wide and very wide facial types was performed in the licensed package "Statistica 6.0" using step-by-step regression analysis.

\section{Results}

Models of teleradiographic indicators by the Steiner method with a coefficient of determination $\left(R^{2}\right)$ greater than 0.6 , which were included in the second group depending on the indicators of the first group in young men with a wide face type have the form of the following linear equations:

angle SNA $=129,1-0,237 \times \mathrm{N}-\mathrm{S}-\mathrm{Ar}+0,373 \times \mathrm{Ar}-\mathrm{Go}-$ $0,382 \times \mathrm{H}\left(R^{2}=0,665 ; F_{(3,18)}=11,90 ; p<0,0002 ;\right.$ Std. Error of estimate $=2,272)$;

angle SNB $=136,5-0,338 \times \mathrm{N}-\mathrm{S}-\mathrm{Ar}+0,495 \times \mathrm{Ar}-\mathrm{Go}-$ $0,419 \times \mathrm{H}\left(R^{2}=0,895 ; F_{(3,18)}=51,15 ; p<0,0000 ;\right.$ Std. Error of estimate $=1,423)$;

angle $S N D=132,3-0,301 \times \mathrm{N}-\mathrm{S}-\mathrm{Ar}+0,490 \times \mathrm{Ar}-\mathrm{Go}-$ $0,444 \times \mathrm{H}\left(R^{2}=0,850 ; F_{(3,18)}=33,95 ; p<0,0000 ;\right.$ Std. Error of estimate $=1,697)$;

angle SN-GoGn $=47,08-0,801 \times \mathrm{Ar}-\mathrm{Go}+0,759 \times \mathrm{H}-$ 2,513 x N-S:S-Ar' - 0,580 x N-S $\left(R^{2}=0,917 ; F_{(4,17)}=46,75\right.$; $p<0,0000$; Std. Error of estimate $=2,016)$;

distance $S-L=75,38+1,019 \times$ Ar-Go - 0,600 $\times$ N-S-Ar + $1,119 \times \mathrm{N}-\mathrm{S}-0,815 \times \mathrm{H}\left(R^{2}=0,888 ; F_{(4,17)}=33,60 ; p<0,0000\right.$; Std. Error of estimate $=3,476)$; where, here and hereafter, $\mathrm{F}_{(\text {(! !!) }}=$ !!! !! - critical (!. !!) and obtained (!!. !!) value of Fisher's criterion; St. Error of estimate - standard error of the standardized regression coefficient.

The coefficients of determination of the regression equations of the value of the angle ANB and the distance Pog-NB in young men with a wide type of face are equal to 0.100 and 0.518 and therefore have no practical significance.

Models of teleradiographic indicators by the Steiner method with a coefficient of determination greater than 0.6 , which were included in the second group depending on the indicators of the first group in young women with a very wide face type have the form of the following linear equations:

angle SNA $=128,2-0,297 \times \mathrm{N}-\mathrm{S}-\mathrm{Ar}-0,513 \times \mathrm{N}-\mathrm{CC}+$ $0,280 \times \mathrm{S}-\mathrm{Ar}+0,223 \times$ Ar-Go $\left(R^{2}=0,604 ; F_{(4,20)}=7,62\right.$; $p<0,0007$; Std. Error of estimate $=2,564)$;

angle SN-GoGn = $-90,82+1,550 \times \mathrm{H}-1,164 \times \mathrm{POr}-\mathrm{NBa}$ $\left(R^{2}=0,623 ; \quad F_{(2,22)}=18,17 ; p<0,0000 ;\right.$ Std. Error of estimate $=2,985)$;

distance $S-L=120,0+0,868 \times \mathrm{N}-\mathrm{Se}-0,807 \times \mathrm{H}-0,373$ x N-S-Ar $\left(R^{2}=0,812 ; F_{(3,21)}=30,14 ; p<0,0000 ;\right.$ Std. Error of estimate $=4,058)$.

The coefficients of determination of the regression equations of the magnitude of the angles SNB and SND and the magnitude of the distance Pog-NB in young women with a very wide face type are from 0.449 to 0.523 and therefore have no practical significance; and the regression equation for the value of the angle ANB is not constructed at all.

Models of teleradiographic indicators by the Steiner method with a coefficient of determination greater than 0.6 , which were included in the second group depending on the indicators of the first group in young women with a wide face type have the form of the following linear equations:

angle SNB $=187,7-0,432 \times$ S-ar:ar-Go + 1,208 x POr$\mathrm{NBa}-0,977 \times \mathrm{H}-0,257 \times \mathrm{N}-\mathrm{Se}\left(R^{2}=0,702 ; F_{(4,19)}=11,17\right.$; $p<0,0001$; Std. Error of estimate $=2,324)$;

angle $S N D=139,1-0,317 \times$ S-ar:ar-Go + 0,907 x POr$\mathrm{NBa}-0,547 \times \mathrm{H}+0,302 \times \mathrm{P}$-PTV $\left(R^{2}=0,694 ; F_{(4,19)}=10,77\right.$; $p<0,0001$; Std. Error of estimate $=2,200)$;

angle SN-GoGn $=30,73-0,483 \times \mathrm{Ar}-\mathrm{Go}-0,676 \times \mathrm{P}-\mathrm{PTV}$ - 0,676 x N-Se + 0,703 x N-CC $\left(R^{2}=0,697 ; F_{(4,19)}=10,91\right.$; $p<0,0001 ;$ Std. Error of estimate $=2,796)$;

distance $S-L=18,67+1,246 \times \mathrm{N}-\mathrm{Se}+1,146 \times \mathrm{P}-\mathrm{PTV}$ $0,519 \times$ S-ar:ar-Go + 1,197 x POr-NBa $\left(R^{2}=0,771\right.$; $F_{(4,19)}=16,00 ; p<0,0000 ;$ Std. Error of estimate $\left.=4,935\right)$.

The coefficients of determination of the regression equation of the value of the SNA angle in young women with a wide type of face is equal to 0.531 and therefore has no practical significance; and the regression equations for the value of the angle ANB and the value of the distance Pog-NB are not constructed at all.

Models of teleradiographic indicators by the Steiner method with a coefficient of determination greater than 0.6 , which were included in the third group depending on the 
indicators of the first and second groups in young men with a wide face type have the form of the following linear equations:

angle II $=144,4+0,842 \times$ SN-GoGn $-1,020 \times$ ANB $0,924 \times \mathrm{S}-\mathrm{E}+1,005 \times \mathrm{N}-\mathrm{CC}-1,019 \times \mathrm{N}-\mathrm{S}\left(R^{2}=0,696\right.$ $F_{(5,16)}=7,31 ; p<0,0010$; Std. Error of estimate $\left.=3,837\right)$;

angle $\mathbf{S N}-\mathbf{O c P}=50,68+0,502 \times \mathrm{SN}-\mathrm{GoGn}-0,265 \times \mathrm{S}-$ $\mathrm{L}-0,397 \times \mathrm{S}-\mathrm{Ar}-0,243 \times \mathrm{H}\left(R^{2}=0,929 ; F_{(4,17)}=55,76\right.$; $p<0,0000$; Std. Error of estimate $=1,607)$;

angle Max1-NA = 39,73 - 1,723 x ANB + 0,391 x S-L 3,776 x N-S:S-Ar' + 0,543 x P-PTV $\left(R^{2}=0,919 ; F_{(4,17)}=48,21\right.$; $p<0,0000$; Std. Error of estimate $=1,875)$;

angle Max1-SN = -49,78 + 2,665 x SNB - 0,969 x SNA $2,581 \times \mathrm{N}-\mathrm{S}: \mathrm{S}-\mathrm{Ar}+0,421 \times \mathrm{N}-\mathrm{S}\left(R^{2}=0,946 ; F_{(4,17)}=74,86\right.$; $p<0,0000$; Std. Error of estimate $=1,984)$;

angle Mand1-NB $=82,50+1,956 \times$ ANB $-0,746 \times \mathrm{SN}-$ GoGn - 0,590 x P-PTV - 0,503 x N-CC - 0,481 x SND $\left(R^{2}=0,745 ; \quad F_{(5,16)}=9,36 ; \quad p<0,0003 ; \quad\right.$ Std. Error of estimate $=3,031)$;

distance 1u-NB $=-17,35+0,246 \times \mathrm{ANB}-0,284 \times \mathrm{P}-\mathrm{PTV}$ - 0,419 x Pog-NB + 0,087 x N-S-Ba $\left(R^{2}=0,662 ; F_{(4,17)}=8,34\right.$; $p<0,0007$; Std. Error of estimate $=0,990)$;

distance Holdaway Ratio = -7,821 - 1,224 x Pog-NB $0,309 \times$ P-PTV + 0,293 x ANB $\left(R^{2}=0,812 ; F_{(3,18)}=25,89\right.$; $p<0,0000 ;$ Std. Error of estimate $=1,079)$.

Only the coefficient of determination of the regression equation of the distance 1u-NA in young men with a wide face type is equal to 0.519 and therefore has no practical significance.

Models of teleradiographic indicators by the Steiner method with a coefficient of determination greater than 0.6, which were included in the third group depending on the indicators of the first and second groups in young women with a very wide face type have the form of the following linear equations:

angle $\mathbf{S N}-\mathbf{O c} \boldsymbol{P}=26,37-1,021 \times \mathrm{SND}+0,248 \times \mathrm{N}-\mathrm{S}-\mathrm{Ar}+$ $0,445 \times \operatorname{SNA}\left(R^{2}=0,672 ; F_{(3,21)}=14,36 ; p<0,0000 ;\right.$ Std. Error of estimate $=2,551)$;

angle Max1-SN = 42,68 + 1,925 x SNB - 0,962 x SNA $0,451 \times$ SN-GoGn - 0,774 x Pog-NB $\left(R^{2}=0,688 ; F_{(4,20)}=11,02\right.$; $p<0,0001$; Std. Error of estimate $=4,149)$;

angle Mand1-NB = 16,64 + 2,356 xANB - 0,631 x S-E + $0,606 \times$ POr-NBa $\left(R^{2}=0,635 ; F_{(3,21)}=12,17 ; p<0,0001\right.$; Std. Error of estimate $=4,127)$;

distance Holdaway Ratio = 8,842 - 1,225 x Pog-NB + $0,450 \times$ ANB $-0,070 \times \mathrm{N}-\mathrm{S}-\mathrm{Ba}+0,146 \times \mathrm{POr}-\mathrm{NBa}\left(R^{2}=0,844\right.$; $F_{(4,20)}=27,11 ; p<0,0000 ;$ Std. Error of estimate $\left.=1,052\right)$.

The coefficients of determination of regression equations of the angle II, distances Max1-NA, 1u-NA and 1I-NB in young women with a very wide face type are from 0.405 to 0.564 and therefore have no practical significance.

Models of teleradiographic indicators by the Steiner method with a coefficient of determination greater than 0.6 , which were included in the third group depending on the indicators of the first and second groups in young women with a wide face type have the form of the following linear equations:

angle SN-OcP $=80,75-4,569 \times$ SND - 0,494 x P-PTV $0,245 \times \mathrm{N}-\mathrm{CC}+3,489 \times \mathrm{SNB}+1,556 \times \mathrm{Pog}-\mathrm{NB}\left(R^{2}=0,868\right.$ $F_{(5,18)}=23,72 ; p<0,0000$; Std. Error of estimate $\left.=1,980\right)$;

angle Max1-SN = -42,97 + 2,855 x SNB - 1,194 x SNA + $0,588 \times$ SN-GoGn $\left(R^{2}=0,617 ; F_{(3,20)}=10,72 ; p<0,0002\right.$; Std. Error of estimate $=4,196)$;

angle Mand1-NB $=-162,6+1,281 \times$ ANB $+11,84 \times \mathrm{N}-$ S:S-Ar' + 0,859 x N-S-Ar - 0,950 x Pog-NB + 0,228 x S-ar:ar$\mathrm{Go}+0,374 \times \mathrm{N}-\mathrm{CC}\left(R^{2}=0,833 ; F_{(6,17)}=14,10 ; p<0,0000\right.$; Std. Error of estimate $=2,731)$;

distance 1u-NA = -4,658 - 0,716 x ANB - 0,470 x Pog$\mathrm{NB}+0,176 \times \mathrm{N}-\mathrm{CC}-0,083 \times \mathrm{Ar}-\mathrm{Go}+0,083 \times \mathrm{SND}\left(R^{2}=0,831\right.$; $F_{(5,18)}=17,69 ; p<0,0000 ;$ Std. Error of estimate $\left.=0,757\right)$;

distance $1 \mathrm{u}-\mathrm{NB}=-5,249-0,588 \times \mathrm{Pog}-\mathrm{NB}+0,284 \mathrm{x}$ $\mathrm{ANB}+0,264 \times \mathrm{N}-\mathrm{CC}-0,092 \times \mathrm{Ar}-\mathrm{Go}\left(R^{2}=0,718 ; F_{(4,19)}=12,07\right.$; $p<0,0001$; Std. Error of estimate $=1,049$ );

distance Holdaway Ratio = -8,447 - 1,513 x Pog-NB + $0,382 \times \mathrm{ANB}+0,232 \times \mathrm{N}-\mathrm{CC}+0,064 \times \mathrm{S}-\mathrm{ar}: \mathrm{ar}-\mathrm{Go}+0,115 \times$ P-PTV $\left(R^{2}=0,923 ; F_{(5,18)}=42,88 ; p<0,0000 ;\right.$ Std. Error of estimate $=1,014)$.

The coefficients of determination of the regression equations of the magnitude of the angle II and the distance Max1-NA in young women with a wide type of face are equal to 0.219 and 0.527 and therefore have no practical significance.

\section{Discussion}

Thus, for young men with a wide facial type, 5 reliable regression models of teleradiographic indicators out of 7 were constructed according to the Steiner method with a coefficient of determination higher than $0.6\left(R^{2}=\right.$ from 0.665 to 0.895 ) which were included in the second group depending on the indicators of the first group. The models most often include: the value of the distance Ar-Go and the angle $\mathrm{H}(29.41 \%$ each), the value of the angle N-S-Ar $(23.53 \%)$ and the distance N-S (11.76\%).

In young women with a very wide facial type, out of 7 possible, only 3 reliable regression models of teleradiographic parameters were constructed according to the Steiner method with a coefficient of determination higher than $0.6\left(R^{2}=\right.$ from 0.604 to 0.812$)$ which were included in the second group depending on the first group data. The models most often include the value of the angles $\mathrm{N}-\mathrm{S}-\mathrm{Ar}$ and $\mathrm{H}$ (22.22\% each).

In young women with a wide face type, out of 7 possible, 4 reliable regression models of teleradiographic indicators were constructed according to the Steiner method with a coefficient of determination higher than $0.6\left(R^{2}=\right.$ from 0.694 to 0.771 ) which were included in the second group depending on the indicators of the first group. The models most often include: the value of the distance P-PTV, the angle POr-NBa and the ratio S-ar:ar-Go (21.43\% each), as well as the angle $\mathrm{H}(14.29 \%)$.

In young men with a wide face type, 7 reliable regression models of teleradiographic indicators out of 8 
were constructed according to the Steiner method with a coefficient of determination higher than $0.6\left(R^{2}=\right.$ from 0.662 to 0.946 ) which were included in the third group depending on the indicators of the first and second groups. The most commonly constructed models include: ANB angle (17.24\%), P-PTV distance (13.79\%), and SN-GoGn angle (10.34\%).

In young women with a very wide face type, out of 8 possible, 4 reliable regression models of teleradiographic indicators were built according to the Steiner method with a coefficient of determination higher than $0.6\left(R^{2}=\right.$ from 0.635 to 0.844 ) which were included in the third group depending on the first and second groups. The constructed models most often include the value of ANB, SNA, POr$\mathrm{NBa}$ angles and Pog-NB distances (14.29\% each).

In young women with a wide face type, out of 8 possible, 6 reliable regression models of teleradiographic indicators were constructed according to the Steiner method with a coefficient of determination higher than $0.6\left(R^{2}=\right.$ from 0.617 to 0.923 ) which were included in the third group depending on the indicators of the first and second groups. The constructed models most often include: the value of the distance Pog-NB (17.86\%) and the value of the angle ANB and the distance N-CC (14.29\% each).

Domestic work on the study of the features of teleradiometric, cephalometric and odontometric indicators among Ukrainians is not isolated, although they still cannot fully meet the needs of clinicians.

Regional features of interrelations of odontometric and cephalometric indicators for men living in the southern region of Ukraine are determined. The largest number of statistically significant relationships was found between molar size and facial size, of which $7.4 \%$ were upper jaw molars and $13.2 \%$ were lower jaw molars. In addition, relationships between skull size and tooth height, root length and facial skull, and vestibular-lingual and mesiodistal tooth sizes have been identified [21].

In a similar work, regression models of individual teleradiographic indicators were constructed by the Ricketts method for adolescents, Ukrainians with different facial types [6].

The study of the influence of facial type on odontometric parameters for the Ukrainian population was partially investigated by a team of authors led by A.V.Marchenko [14].

If we analyze the foreign work performed in this area, we can also see the logical conclusions about the existence of features of teleradiographic indicators within different populations [19, 20]. A.M. Aldrees [1] conducted a metaanalysis of the results of various types of work where we studied the features of teleradiographic indicators for the population of Saudi Arabia. Out of 485 studies devoted to this topic, the author selected 8 that met the inclusion criterion. The analysis confirmed the significance of the differences between the Arabs and the control indicators on the basis of European data, namely - the Arabs have more convex facial profiles and more inclined incisors.

Kurds living in Iran have significant differences $(p<0.05)$ with SNA, SNB, ANB, SND, incisor angle, GoGn-SN L1-NB, $S L$ and SE compared to normative Steiner data. At the same time, no significant difference was found between the studied indicators in Kurdish men and women $(p>0.05)$ [11].

Also, significant differences were found in the study of ethnic Malays, residents of Malaysia. The local population has a more anterior location of both the upper and lower jaws, protrusion of the upper and lower lips and a less pronounced chin than the Steiner's European data [15].

The largest difference for the Moroccan sample compared to Steiner's data was shown in terms of skeletal parameters in the sagittal direction, as well as the assigned position of the upper and lower jaws. In addition, the authors of the study draw attention to the fact that the sample was based on the inhabitants of Casablanca and therefore in the future it is necessary to study the regional characteristics of indicators within Morocco [16].

Thus, the results of this study are in line with global trends in the study of teleradiography in different ethnic and regional groups. Modeling of individual teleradiographic indicators by the Steiner method for members of the Ukrainian population taking into account age, sex and face type is a successful step in approximating a personalized approach to the methodology of planning orthodontic treatment in order to achieve the best functional and aesthetic results.

\section{Conclusions}

1. In young men with a wide type of face according to the Steiner method, 5 reliable models of teleradiographic indicators with a coefficient of determination higher than 0.6 were included in the second group depending on the indicators of the first group $\left(R^{2}=\right.$ from 0.665 to 0.895$)$ and 7 models included in the third groups depending on the indicators of the first and second groups $\left(\mathrm{R}^{2}=\right.$ from 0.662 to $0.946)$; in young women with a very wide type of face respectively only $3\left(R^{2}=\right.$ from 0.604 to 0.812$)$ and $4\left(R^{2}=\right.$ from 0.635 to 0.844 ) models; in young women with a wide face type - respectively $4\left(R^{2}=\right.$ from 0.694 to 0.771$)$ and 6 $\left(\mathrm{R}^{2}=\right.$ from 0.617 to 0.923$)$ models.

2. In young men with a wide type of face among the teleradiographic indicators of the first group included in the models of the second group according to the Steiner method most often included the value of the distance ArGo and angle $\mathrm{H}$ (29.41\% each), angle N-S-Ar (23.53\%) and distance N-S (11.76\%); in young women with a very wide type of face - the value of the angles N-S-Ar and $\mathrm{H}$ $(22.22 \%$ each); in young women with a wide type of face the value of the distance P-PTV, the angle POr-NBa and the ratio of S-ar:ar-Go (21.43\% each) and the angle $\mathrm{H}(14.29 \%)$.

3 . In young men with a wide type of face among the teleradiographic indicators of the first and second groups included in the models of indicators of the third group 
according to the Steiner method most often included the value of the ANB angle (17.24\%), P-PTV distance (13.79\%), and also the angle SN-GoGn (10.34\%); in young women with a very wide type of face - the value of the angles ANB,

\section{References}

[1] Aldrees, A.M. (2011). Lateral cephalometric norms for Saudi adults: A meta-analysis. The Saudi Dental Journal, 23(1), 37. doi: $10.1016 /$ j.sdentj.2010.09.002

[2] Devereux, L., Moles, D., Cunningham, S.J., \& McKnight, M. (2011). How important are lateral cephalometric radiographs in orthodontic treatment planning? American Journal of Orthodontics and Dentofacial Orthopedics, 139(2), e175e181. doi: 10.1016/j.ajodo.2010.09.021

[3] Dmitriev, M.O. (2017). Зв'язки основних краніальних показників з характеристиками положення зубів верхньої і нижньої щелеп та профрілем м'яких тканин обличчя в юнаків і дівчат [Relations of key cranial indicators with the characteristics of the teeth of the upper and lower jaws and profile face soft tissue in boys and girls]. Вісник морфоологіï - Reports of Morphology, 23(1), 125-131.

[4] Dmitriev, M., Gunas, V., Polishchuk, S., Olkhova, I., \& Kumar, A. (2020). Modeling of Central Incisors Position Indicators in boys and girls according to CC. Steiner method for Forensic Dental Identification. The Official Publication of Indian Academy of Forensic Medicine, 42(3), 155-160. doi: 10.5958/09740848.2020.00043.3

[5] Doroshenko, S.I., \& Kulginsky, Е.А. (2007). Основы телерентгенографиu [Fundamentals of Teleradiography]. К.: Здоров'я - K.: Zdorovija.

[6] Drachevska, I.Yu. (2021). Regression models of individual teleradiographic indicators according to Ricketts method in Ukrainian young men and young women with different face types. Вісник Вінницького національного медичного унівepcumemy - Reports of Vinnytsia National Medical University, 25(2), 238-246. doi: 10.31393/reports-vnmedical2021-25(2)-09

[7] Durão, A.R., Alqerban, A., Ferreira, A.P., \& Jacobs, R. (2015). Influence of lateral cephalometric radiography in orthodontic diagnosis and treatment planning. The Angle Orthodontist, 85(2), 206-210. doi: 10.2319/011214-41.1

[8] Govinakovi, P.S., Al-Busaidi, I., \& Senguttuvan, V. (2018). Cephalometric Norms in an Omani Adult Population of Arab Descent. Sultan Qaboos University Medical Journal, 18(2), e182-e189. doi: 10.18295/squmj.2018.18.02.010

[9] Gunas, V.I., Kotsyura, O.O., Babych, L.V., Shevchuk, Y.G., \& Cherkasova, O.V. (2020). Features correlations of the sizes of molars with cephalometric indicators of men of the western region of Ukraine. Reports of Morphology, 26(2), 51-61. doi: 10.31393/morphology-journal-2020-26(2)-08

[10] Helal, N.M., Basri, O.A., \& Baeshen, H.A. (2019). Significance of cephalometric radiograph in orthodontic treatment plan decision. J. Contemp. Dent. Pract., 20(7), 789-793. doi:
SNA, POr-NBa and the distance Pog-NB (14.29\% each); in young women with a wide type of face - the value of the distance Pog-NB (17.86\%), the angle ANB and the distance N-CC (14.29\% each).

10.5005/jp-journals-10024-2598

[11] Imani, M.M., Farzaneh, S., Ghanbari, A., \& Arab, S. (2019). Cephalometric norms in an Iranian Kurdish population according to the Steiner analysis. Iranian Journal of Orthodontics, 14(1), e63439. doi: $10.5812 /$ ijo.63439

[12] Kolokitha, O.E., \& Topouzelis, N. (2011). Cephalometric methods of prediction in orthognathic surgery. Journal of Maxillofacial and Oral Surgery, 10(3), 236. doi: 10.1007/s12663-011-02287

[13] Lyakhova, N.A. (2018). Analysis of Risk Factors of Orthodontic Pathology: Literature Review. Wiadomosci Lekarskie (Warsaw, Poland: 1960), 71(5), 1084-1088.

[14] Marchenko, A.V., Shinkaruk-Dykovytska, M.M., Pozur, T.P., Gunas, V.I., \& Orlovskiy, V.O. (2020). Models of individual linear dimensions necessary for the construction of the correct form of dental arches in young men with a wide face, depending on the features of odontometric and cephalometric indicators. Wiadomosci Lekarskie (Warsaw, Poland: 1960), 73(6), 11031107. PMID: 32723934

[15] Mohammad, H.A., Hassan, A., \& Hussain, S.F. (2011). Cephalometric evaluation for Malaysian Malay by Steiner analysis. Scientific Research and Essays, 6(3), 627-634. doi: $10.5897 /$ SRE10.869

[16] Ousehal, L., Lazrak, L., \& Chafii, A. (2012). Cephalometric norms for a Moroccan population. International Orthodontics, 10(1), 122-134. doi: 10.1016/j.ortho.2011.12.001

[17] Phulari, B. (2013). An atlas on cephalometric landmarks. JP Medical Ltd. doi: $10.5005 / \mathrm{jp} /$ books $/ 11877$

[18] Profit, W.R. (2017). Современная ортодонтия (4-е изд., пер. с англ.) [Modern orthodontics (4th ed., trans. from English)]. М.: МЕДпресс-информ - М.: MEDpress-inform.

[19] Rathore, A.S., Dhar, V., Arora, R., \& Diwanji, A. (2012). Cephalometric norms for Mewari children using Steiner's analysis. International Journal of Clinical Pediatric Dentistry, 5(3), 173-177. https://doi.org/10.5005/jp-journals-10005-1161

[20] Sharma, J.N. (2011). Steiner's cephalometric norms for the Nepalese population. Journal of Orthodontics, 38(1), 21-31. doi: $10.1179 / 14653121141209$

[21] Soboń, J.S., Cherkasova, O.V., Gunas, V.I., Babych, L.V., \& Kotsyura, O.O. (2020). Correlations of linear sizes of molars with cephalometric indicators of practically healthy men of the southern region of Ukraine. Biomedical and Biosocial Anthropology, (38), 36-46. https://doi.org/10.31393/bba382020-06

[22] Steiner, C.C. (1959). Cephalometrics in clinical practice. Angle Orthod., (29), 8-29. doi: 10.1043/00033219(1959)029<0008:CICP>2.0.CO;2

\section{МОДЕЛЮВАННЯ ІНДИВІДУАЛЬНИХ ТЕЛЕРЕНТГЕНОГРАФІЧНИХ ПОКАЗНИКІВ ЗА МЕТОДОМ STЕІNЕR В УКРАÏНСЬКИХ ЮНАКІВ ІЗ ШИРОКИМ ТА ДІВЧАТ ІЗ ДУЖЕ ШИРОКИМ І ШИРОКИМ ТИПАМИ ОБЛИЧЧЯ \\ Драчевська І.Ю.}

Цефралометричні методи аналізу бокових телерентгенограм є одним із ключових елементів ортодонтичного планування лікування пацієнта з патологією зубо-щелепної системи. Визначення нормативних телерентгенографічних показників для місцевої популяції населення є ключовим етапом для успішного застосування тієї чи іншої методики аналізу, зокрема, і для України. Мета дослідження - в українських юнаків і дівчат з ортогнатичним прикусом з різними типами обличчя побудувати та провести аналіз регресійних моделей телерентгенографрічних показників, що використовують у методиці Steiner. 49

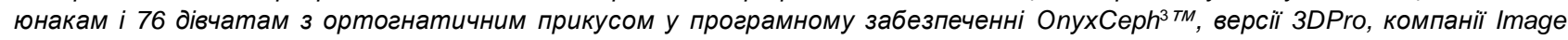


Instruments GmbH, Німеччина (ліцензія № URSQ-1799) проведено цефалометричне дослідження за методикою Steiner. Розподіл на типи обличчя проводили за допомогою індексу Гарсона. Цефалометричні показники були розділені на три групи: перша - показники, що використовують у цефалометричних аналізах Schwarz, Ricketts, Steiner, Roth-Jarabak, Burstone i Bjork і входять до параметрів, які зазвичай не змінюються під час хірургічного та ортодонтичного лікування; друга - зубощелепні характеристики за методом Steiner, яким хірургічними методами можна змінювати довжину, ширину, кути та положення щелеп; третя - показники за методом Steiner, які характеризують положення кожного зуба відносно один одного, черепних структур та профілю м'яких тканин обличчя. Моделювання індивідуальних телерентгенгографрічних показників проведено в ліцензійному пакеті "Statistica 6,0" за допомогою покрокового регресійного аналізу. При аналізі достовірних моделей телерентгенографрічних показників за методикою Steiner, які увійшли до другої групи, в залежності від показників першої групи із коефріцієнтом детермінації вищим 0,6, встановлено, що із 7 можливих в юнаків із широким типом обличчя побудовано 5 моделей $\left(R^{2}=\right.$ від 0,665 до 0,895), до яких найбільш часто входять величина відстаней Ar-Go i N-S ma кутів $H$ i N-S-Ar; у дівчат з дуже широким типом обличчя - 3 моделі $\left(R^{2}=\right.$ від 0,604 до 0,812), до яких найбільш часто входять величина кутів N-S-Ar i H; у дівчат із широким типом обличчя - 4 моделі $\left(R^{2}=\right.$ від 0,694 до 0,771), до яких найбільш часто входять величина кутів POr-NBa та H, відстані P-PTV і співвідношення S-ar : ar-Go. При аналізі достовірних моделей телерентгенографрічних показників за методикою Steiner, які увійшли до третьої групи в залежності від показників першої та другої груп із коефріцієнтом детермінації вищим 0,6, встановлено, що із 8 можливих в юнаків із широким типом обличчя побудовано 7 моделей ( $R^{2}=$ від 0,662 до 0,946), до яких найбільш часто входять величина кутів ANB i SN-GoGn та відстані P-PTV; у дівчат із дуже широким типом обличчя - 4 моделі $\left(R^{2}=\right.$ від 0,635 до 0,844), до яких найбільш часто входять величина кутів ANB, SNA, POr-NBa та відстані Pog-NB; у дівчат із широким типом обличчя - 6 моделей ( $R^{2}=$ від 0,617 до 0,923), до яких найбільш часто входять величина відстаней Pog-NB i N-CC та кута ANB. Побудова регресійних моделей телерентгенографрічних показників, що використовують у методиці Steiner в українських юнаків і дівчат із ортогнатичним прикусом є фундаментом для створення в Україні бази нормативних цефалометричних показників, що дозволить надавати стоматологічну допомогу населенню на сучасному рівні.

Ключові слова: регресійний аналіз, телерентгенографрія, цефралометрія за методикою Steiner, юнаки та дівчата 3 ортогнатичним прикусом, типи обличчя. 